\title{
Fast Fashion for 2030: Using the Pattern of the Sustainable Development Goals (SDGs) to Cut a More Gender-Just Fashion Sector
}

\author{
Ramona Vijeyarasa ${ }^{1 *}$ (D) and Mark Liu ${ }^{2}$ \\ ${ }^{1}$ Senior Lecturer, Faculty of Law, University of Technology Sydney, Australia and Women's Leadership \\ Institute Australia Research Fellow (2020-2022) \\ ${ }^{2}$ Visiting Scholar, School of Architecture, University of Technology Sydney, Australia \\ *Corresponding author. Email: ramona.vijeyarasa@uts.edu.au
}

\begin{abstract}
The 2013 collapse of the Rana Plaza in Bangladesh brought global visibility to the human rights abuses experienced by women workers in the garment sector. As the spotlight on this incident dims, the need to hold the fashion sector accountable remains. In this article, we suggest that greater accountability could be achieved through the application of a human rights-informed understanding of the Sustainable Development Goals (SDGs) to promote gender justice in the sector. By drawing on international women's rights law and sustainable fashion, we demonstrate how sustainability and gender justice are intimately connected, and illustrate what role the SDGs can play in promoting sustainable outcomes that are gender-just. The article unpacks concepts such as sustainability, the circular economy, social responsibility, and ethical fashion, and places the experiences of women workers within this context. Its principal contribution is a set of six requirements to ensure a gender perspective to the fashion industry's role in implementing the SDGs.
\end{abstract}

Keywords: garment sector; gender justice; migrant workers; Sustainable Development Goals (SDGs); sustainable fashion

\section{Introduction}

In a garment factory fire in Manhattan on 25 March 1911, over 100 people, mostly Jewish and Italian women migrants, some as young as 14 , died as the factory burnt to the floor because management had locked the doors. ${ }^{1}$ In the years that followed, women workers mobilized. These protests catalysed major law reforms in the United States of America (USA) including social security and unemployment insurance, abolition of child labour, the setting of a minimum wage, and agreements on the right to join a union, all of which are enjoyed today.

Despite the century in between, parallels can be drawn between the 1911 Manhattan factory fire and the 2013 collapse of the Rana Plaza in the Savar Upazila district of Dhaka, Bangladesh, in which 1,134 people were killed and 2,500 were injured, mostly young

\footnotetext{
${ }^{1}$ Brenda Lange, The Triangle Shirtwaist Factory Fire (New York: Infobase Publishing, 2009); Arthur F McEvoy, 'The Triangle Shirtwaist Factory Fire of 1911: Social Change, Industrial Accidents, and the Evolution of CommonSense Causality' (1995) 20:2 Law and Social Inquiry 621.

(c) The Author(s), 2021. Published by Cambridge University Press. This is an Open Access article, distributed under the terms of the Creative Commons Attribution licence (http://creativecommons.org/licenses/by/4.0), which permits unrestricted re-use, distribution and reproduction, provided the original article is properly cited.
} 
women. ${ }^{2}$ The collapse has been described as the worst garment factory disaster in modern human history. ${ }^{3}$ While the collapse triggered mass protests and what some have called 'unprecedented international scrutiny', ${ }^{4}$ years on, accountability for the resulting safety accords remains insufficient as many factories continue to escape scrutiny. ${ }^{5}$ Furthermore, the challenges posed in trying to delineate responsibility between factories on the one hand, and sourcing companies (the brands) on the other, too often results in these sourcing companies avoiding responsibility.

Rana Plaza is just one example that is symptomatic of a larger global fashion sector in which gender inequalities remain rife. ${ }^{6}$ While there are particularities in certain countries and regions where textiles, clothing and footwear (TCF) form a large portion of national exports, the problem is a global one, requiring a global solution. The United Nations 2030 Agenda for Sustainable Development, including the Sustainable Development Goals (SDGs), are considered central to fashion - the sector being the second largest polluting industry in the world. ${ }^{7}$ The link between the SDGs, inequalities and rights at work, for example, are demonstrated in particular in Goals 1, 5, 8, 10 and 17.

Building on these established linkages between the fashion industry and the SDGs, our article revisits the goals of sustainable and gender-just fashion. We demonstrate how the SDGs provide a useful framework for facilitating a more gender-just approach to the fast fashion sector, especially when sustainable development is understood as firmly grounded in human rights.

In our analysis, we draw on two areas of scholarship - international women's rights law and feminist sociolegal research on the one hand, and sustainable fashion on the other. We layer upon this a new lens to the SDGs through the authors' practical experiences as, in one case, a women's rights practitioner and scholar of international law ${ }^{8}$ and in the other instance, a fashion designer and scholar of sustainable fashion. ${ }^{9}$ Our goal is to broaden the scope of the debate by highlighting the gendered concerns that are often given inadequate

\footnotetext{
${ }^{2}$ Rashedur Chowdhury, 'The Rana Plaza Disaster and the Complicit Behavior of Elite NGOs' (2017) 24:6 Organization 938.

${ }^{3}$ International Labour Organization, ‘The Rana Plaza Accident and its Aftermath', https://www.ilo.org/global/ topics/geip/WCMS_614394/lang-en/index.htm (accessed 2 June 2021).

4 Jonathan Jacoby, 'What's Changed (and What Hasn't) Since the Rana Plaza Nightmare', Open Society Foundations: Voices (24 April 2018), https://www.opensocietyfoundations.org/voices/what-s-changed-and-what-hasn-t-ranaplaza-nightmare (accessed 2 June 2021).

${ }^{5}$ Paul M Barrett, Dorothée Baumann-Pauly and April Gu, Five Years After Rana Plaza: The Way Forward, New York: NYU Stern Center for Business and Human Rights, 2018 http://static1.squarespace.com/static/ 547df270e4b0ba184dfc490e/t/5ac9514eaa4a998f3f30ae13/1523143088805/NYU+Bangladesh+Rana+Plaza+Report.pdf (accessed 2 June 2021).

${ }^{6}$ Mia M Rahim, 'Humanising the Global Supply Chain: Building a Decent Work Environment in the Readymade Garments Supply Industry in Bangladesh' in Surya Deva and David Birchall (eds.), Research Handbook on Human Rights and Business (Massachusetts: Edward Elgar Publishing, 2020) 130, 140.

7 See UN Environment Programme, 'Putting the Brakes on Fast Fashion', News and Stories (12 November 2018), http://www.unep.org/news-and-stories/story/putting-brakes-fast-fashion (accessed 6 August 2021). See also Morgan McFall-Johnsen, 'These Facts Show How Unsustainable the Fashion Industry Is', World Economic Forum (31 January 2020), https://www.weforum.org/agenda/2020/01/fashion-industry-carbon-unsustainable-environ ment-pollution/ (accessed 6 August 2021).

${ }^{8}$ Ramona Vijeyarasa, who is a scholar of gender equality, the law and development, worked as a practitioner for ten years for local and international non-government organizations (NGOs) and international organizations.

${ }_{9}^{9}$ Mark Liu is a fashion and textile designer whose most recent project is a deep exploration of zero-waste fashion.
} 
attention in the fashion sector, partly as a result of the lack of women at the decision-making table..$^{10}$

One of the key barriers to fulfilling the rights of women workers in the fashion sector is that sustainability is not necessarily understood as requiring a gender perspective. While some scholars suggest that gendered considerations have been an 'integral' part of the international sustainability discourse since the early $1990 \mathrm{~s},{ }^{11}$ others, writing in the context of gender and climate change policy debates, are more sceptical, noting the failure to embrace gendered considerations in all of their complexity. ${ }^{12}$ Although women's organizations have argued for a more central place for gender in such debates, when coupled with a 'low level of comprehension' of what constitutes gender among decision-makers, the end result has been a 'distinct air of additionality' rather than a genuine embrace of a gender perspective in many discourses on sustainability. ${ }^{13}$ In other words, we continue to struggle with gender being treated as an add-on rather than a central and core part of policy design.

In this paper, we take the view that a human rights-informed understanding of the SDGs can provide entry points for addressing some of these shortcomings. Specifically, we adopt the perspective that both sustainability and gender justice are indispensable and intertwined, calling for a dramatic re-imagining of the close relationship between the two. In this article, we understand gender justice as an outcome that promotes equitable relationships between women and men, that acknowledges the particular vulnerabilities of marginalized and excluded groups of women, and considers the rights of women to be fundamental to how we define and shape the policies that affect their lives. ${ }^{14}$ In some respects, Goal 5 of the SDGs (gender equality) attempts to underpin this message by highlighting the centrality of gender to achieving all SDGs.

Although this article offers an extensive critique of the garment sector, we acknowledge the importance of garment sector work for women workers, including for household welfare. ${ }^{15}$ In Cambodia, for example, in 2013, the manufacturing sector accounted for 45 per cent of all women's waged employment; ${ }^{16} 90$ per cent of the sectors' workers were women, the majority of whom were young migrants from rural areas. ${ }^{17}$ The solution, therefore, is not to be found simply in alternative employment for these women but in steps to make the industry gender-just. Infusing a gender perspective, and understanding the inter-relationship between gender and sustainability, is particularly important given that many technologies needed to drive more sustainable fashion are in their infancy. We therefore seek to provide policy-makers, governments and businesses with

\footnotetext{
${ }^{10}$ Ramona Vijeyarasa, 'Women, Work and Global Supply Chains: The Gender-Blind Nature of Australia's Modern Slavery Regulatory Regime' (2020) 26:1 Australian Journal of Human Rights 84.

${ }^{11}$ Beate Littig, 'Good Work? Sustainable Work and Sustainable Development: A Critical Gender Perspective from the Global North' (2018) 15:4 Globalizations 565.

12 Susan Buckingham and Virginie Le Masson, 'Introduction' in Susan Buckingham and Virginie Le Masson (eds.), Understanding Climate Change through Gender Relations (London: Routledge, 2017) 1, 3.

${ }^{13}$ Ibid, 2.

${ }^{14}$ Oxfam International, ‘Gender Justice and Women's Rights’, https://www.oxfam.org/en/what-we-do/issues/ gender-justice-and-womens-rights (accessed 16 September 2021).

15 Fauzia E Ahmed, 'The Rise of the Bangladesh Garment Industry: Globalization, Women Workers, and Voice' (2004) 16:2 National Women's Studies Association Journal 34. See also Naila Kabeer, 'Globalization, Labor Standards, and Women's Rights: Dilemmas of Collective (In)Action in an Interdependent World' (2004) 10:1 Feminist Economics 3, whose analysis reminded us that while women workers would unsurprisingly like to see improved working conditions, care must be taken to ensure that advocacy to enhance global labour standards does not result in declining employment or a transfer of work to the informal sector.

${ }^{16}$ Asian Development Bank, Promoting Women's Economic Empowerment in Cambodia (Philippines: Asian Development Bank, 2015) 24 .

${ }^{17}$ Ibid, 25.
} 
practical responses, accepting as a starting point the clear intersections between gender and sustainability. ${ }^{18}$

In section II, we set out the context in which women participate in the fashion sector globally - as workers and consumers, but rarely as decision-makers. We also discuss concepts such as sustainability, corporate accountability, and the circular economy. In section III, we introduce the SDG framing of the fast fashion sector, including the link between sustainable development and existing business and human rights (BHR) frameworks. Section III concludes by elaborating on the potential and limitations of existing domestic and global legal frameworks for addressing gender inequality and exploitation. We use this brief analysis as a springboard for our suggestions on how to promote greater gender justice in the fashion sector through the lens of the SDGs. Section IV, which forms the core of this article and our main discussion of the SDGs, views the fashion sector through six requirements identified by the authors, which we propose are essential to deliver more gender-just and sustainable outcomes. Our goal is to demonstrate why and how issues such as responsible consumption, taxation and participation should be viewed through a gender perspective and how the SDGs offer concrete targets by which governments and businesses can be held to account. While acknowledging the SDGs' limitations, this article provides solutions for how the existing SDGs framework, and the significant policy and financial attention it has attracted, can be used to advance gender justice in the fashion sector.

\section{The Sector: Women and their Experiences of the Fast Fashion Industry}

Women workers dominate the fast fashion industry, particularly in South and Southeast Asia, ${ }^{19}$ where much of the global garment supply occurs. Women form the majority of the workforce: in 2018, both $\mathrm{H} \& \mathrm{M}^{20}$ and Inditex ${ }^{21}$ reported a workforce composed of 74 per cent and 75 per cent women. As will be demonstrated, current global policies and national laws do not adequately regulate the sector, its supply chains, or its impact on workers, particularly when we demand a gender perspective to these laws and policies.

\section{Women and Fast Fashion}

The workplace policies of companies engaged in the fashion industry - often part of large and complex supply chains - have a disparate effect on women and men. Mia Mahmudur Rahim offers a useful definition of global supply chains as a quasi-hierarchical relationship between buyers and producers; a long-term relationship in which the dominant party is the buyer who defines the standards that must be met by all parties in the supply chain. ${ }^{22}$ A central element in the system's design is the tendency for multi-national retailers and brands to source their products from labour-intensive countries, where the 'desperate'

\footnotetext{
${ }^{18}$ Inga T Winkler and Margaret L Satterthwaite, 'Leaving No One behind? Persistent Inequalities in the SDGs' (2017) 21:8 International Journal of Human Rights 1073.

19 Joanna Bourke Martignoni and Elizabeth Umlas, 'Gender-Responsive Due Diligence for Business Actors: Human Rights-Based Approaches', Geneva Academy, Academy Briefing No. 12 (December 2018), 30, fn 98; Petra Dannecker, 'Collective Action, Organisation Building, and Leadership: Women Workers in the Garment Sector in Bangladesh' (2000) 8 Gender and Development 31.

${ }^{20}$ H\&M Group, Annual Report 2018 (Stockholm:H\&M Group, 2018), https://about.hm.com/content/dam/hmgroup/ groupsite/documents/masterlanguage/Annual\%20Report/Annual\%20Report\%202018.pdf (accessed 2 June 2021 ), 37.

${ }^{21}$ Inditex, Annual Report 2018 (Arteixo: Inditex S.A. 2018), https://static.inditex.com/annual_report_2018/pdfs/ en/Inditex\%20Annual\%20Report\%202018.pdf (accessed 2 June 2021), 62.

${ }^{22}$ Rahim, note 6, 132.
} 
desire of governments to obtain and maintain foreign income leads to weak standards from the host country (i.e., where the operations occur) for wages and work conditions. ${ }^{23}$

Underlying the entire system is informality. ${ }^{24}$ Informal labour - untaxed and unregulated - is at times the most dominant feature of employment relations in countries such as India ${ }^{25}$ and Cambodia, ${ }^{26}$ and to a lesser degree Bangladesh. ${ }^{27}$ Where informality is widespread, some scholars place far greater importance on oversight and accountability of states to fulfil their obligations to protect human rights, given the limitations in seeking accountability from corporations. ${ }^{28}$

In both formal and informal contexts, experiences of inequality manifest in many complex ways. These include gender pay gaps; sexual harassment and violence; lack of access to remedies for abuses of women's rights; and lack of protection for women's human rights defenders. ${ }^{29}$ One well-documented example from the garment sector highlights the lack of hydration and restroom breaks which have increased the risks of urinary tract infections faced by women workers. Sexual and reproductive health rights are further undermined by lack of soap, water and sanitary napkins. ${ }^{30}$ Such experiences are endemic in countries that are the world's primary producers of fast fashion, including India, Pakistan and Bangladesh. ${ }^{31}$

Women's experiences as workers in sweatshops and the commodification and exploitation of garment workers are two sides of the same coin. ${ }^{32}$ The transition from fashion being produced by skilled, primarily male, artisans to mass assembly lines of unskilled, poorly remunerated workers has led to the feminization of the labour force. ${ }^{33}$ Women fashion workers are paid less as they are viewed as secondary earners who are easier to discipline, and less likely to negotiate and unionize. ${ }^{34}$ These risks are exacerbated under more

\footnotetext{
${ }^{23}$ Ibid.

${ }^{24}$ Rashmi Venkatesan, 'The UN Framework on Business and Human Rights: A Workers' Rights Critique' (2019) 157:3 Journal of Business Ethics 635.

25 Ibid.

${ }^{26}$ Dennis Arnold and Toh Han Shih, 'A Fair Model of Globalisation? Labour and Global Production in Cambodia' (2010) 40:3 Journal of Contemporary Asia 401, 417.

${ }^{27}$ Nazneen Ahmed and Dev Nathan, 'Improving Wages and Working Conditions in the Bangladesh Garment Sector: The Role of Horizontal and Vertical Relations' in Dev Nathan, Meenu Tewari and Sandip Sarkar (eds.), Labour in Global Value Chains in Asia (Cambridge: Cambridge University Press, 2016) 51, 53. Ahmed and Nathan note that there is some informal garment work in Bangladesh, although on a much smaller scale than in India. Part of the reason is the reality that some of the smaller units of informal supply have not been able to compete with the more formalized supply of large volumes of units.

${ }^{28}$ Venkatesan, note 24, 636.

${ }^{29}$ Miet Maertens and Johan Swinnen, 'Gender and Modern Supply Chains in Developing Countries' (2012) 48:10 Journal of Development Studies 1412, 1413.

${ }^{30}$ Erika George et al, 'Recognizing Women's Rights at Work: Health and Women Workers in Global Supply Chains' (2017) 35:1 Berkeley Journal of International Law 1.

31 Zofeen Ebrahim, 'Pakistan Garment Industry Reforms Fail to Stop Abuses: Activists', Reuters (23 January 2019), https://www.reuters.com/article/us-pakistan-labour-rights-idUSKCN1PH097 (accessed 2 June 2021); Apoorva Kaiwar, 'Gendered Violence in Ready Made Garment Factories in Bangalore', Garment Workers United (6 September 2014), https://garmentworkersunited.wordpress.com/2014/09/06/the-indian-garment-industry-gendered-vio lence-and-human-rights-abuses-in-bangalore/ (accessed 2 June 2021); Patrick Scott, 'Fashion Firms Urged to Address Indian Worker Woes', Just-Style.Com (27 November 2012), https://www.just-style.com/analysis/fashionfirms-urged-to-address-indian-worker-woes_id116260.aspx (accessed 2 June 2021).

32 Alessandra Mezzadri, The Sweatshop Regime: Labouring Bodies, Exploitation, and Garments 'Made in India' (Cambridge: Cambridge University Press, 2016).

${ }^{33}$ Ibid, 86-87.

${ }^{34}$ Ibid, 86-88.
} 
casualized, informal and vulnerable working conditions ${ }^{35}$ where women workers face additional discrimination and harassment.

While the garment sector has offered women an opportunity for economic independence, it has not yet resulted in their economic empowerment as women continue to face barriers in decision-making processes and control of their income. In short, the gendered nature of the fashion sector and the gendered impacts of the inequality it creates and sustains are well documented. A nuanced gender-just response is therefore essential.

\section{Understanding Sustainability, Corporate Accountability and the Circular Economy}

Before moving to the core of this article, it is important to provide some context in terms of how we understand the concept of sustainability. Jennifer Farley Gordon and Colleen Hill frame sustainable fashion as encompassing 'a scope of fashion production or design methods that are environmentally and/or ethically conscious', with the term 'sustainable' often used interchangeably with 'eco', 'green' or 'organic'. ${ }^{36}$ At the same time, scholars acknowledge the lack of a consensus over the definition. ${ }^{37}$ This is due, in large part, to the subjectivity that surrounds sustainability, making it a term which is 'intuitively understood, yet has no coherent definition'. ${ }^{38}$

A further definitional challenge is the general absence of environmental standards that have been enacted specifically for the fashion industry. This absence of sector-specific regulations risks confusion within the sector and a definition of 'sustainable fashion' that is open to interpretation. ${ }^{39}$ Entire articles and literature reviews have been devoted to the plethora of definitions of 'sustainable fashion'. ${ }^{40}$ According to one such review, sustainable fashion has become a 'broad term for clothing and behaviours that are in some way less damaging to people and/or the planet.'11

'Sustainable fashion' is frequently embedded in the 'circular economy' concept, an approach that aims for a mode of utilization of materials in manufacturing that is infinitely recyclable: a continuing - circular - chain. This notion of a circular economy is popular with both business and policy-makers. ${ }^{42}$ Yet there is no universal definition ${ }^{43}$ and over 114 different definitions of 'circular economy' have been identified. ${ }^{44}$ These definitions tend to include the principles of reduce, reuse, recycle and recover ${ }^{45}$ For this discussion, put simply,

\footnotetext{
${ }^{35}$ Archana Prasad, 'De-Feminization and (Dis)Empowerment of Women Workers in Garment Factories' (2018) 3:1 Antyajaa: Indian Journal of Women and Social Change 12.

${ }^{36}$ Lindsey Carey and Marie-Cécile Cervellon, 'Ethical Fashion Dimensions: Pictorial and Auditory Depictions through Three Cultural Perspectives' (2014) 18:4 Journal of Fashion Marketing and Management 483.

${ }^{37}$ Jennifer Farley Gordon and Colleen Hill, Sustainable Fashion: Past, Present and Future (New York: Bloomsbury, 2015), xv.

${ }^{38}$ Claudia E Henninger, Panayiota J Alevizou and Caroline J Oates, 'What is Sustainable Fashion?' (2016) 20:4 Journal of Fashion Marketing and Management 400, 402.

${ }^{39}$ Farley Gordon and Hill, note 37, xv.

${ }^{40}$ Henninger, Alevizou and Oates, note 38; Amira Mukendi et al, 'Sustainable Fashion: Current and Future Research Directions' (2020) 54:11 European Journal of Marketing 2873; Kirsi Niinimäki, 'Ethical Foundations in Sustainable Fashion' (2015) 1 Textiles and Clothing Sustainability 3.

${ }^{41}$ Mukendi et al, note 40, 2873.

${ }^{42}$ World Economic Forum, Towards the Circular Economy: Accelerating the Scale-up Across Global Supply Chains (Geneva: World Economic Forum, 2014).

43 Zengwei Yuan, Jun Bi and Yuichi Moriguchi, 'The Circular Economy: A New Development Strategy in China' (2006) 10:1-2 Journal of Industrial Ecology 4, 5.

${ }^{44}$ Julian Kirchherr, Denise Reike and Marco Hekkert, 'Conceptualizing the Circular Economy: An Analysis of 114 Definitions' (2017) 127 Resources, Conservation and Recycling 221.

45 Ibid.
} 
the circular economy concept describes an industrial economy with a zero-waste approach, where generation of waste and pollution is minimized by maintaining the value of products and materials for longer, in part, by keeping them in circulation. ${ }^{46}$

Sustainable fashion can also encompass the umbrella term 'ethical fashion'. Catrin Joergens defines ethical fashion as 'clothes that incorporate fair trade principles with sweatshop-free labour conditions while not harming the environment or workers by using biodegradable and organic cotton' ${ }^{47}$ Anders Haug and Jacob Busch, in their analysis, acknowledge Joergens as the most cited on the topic of 'ethical fashion' but offer a counter approach. ${ }^{48}$ Instead of a focus on output, they focus on the central roles of the producer and the buyer in ethical fashion and identify the ethical obligations of the actors involved in the production, mediation and consumption of fashion objects. ${ }^{49}$

Social responsibility in relation to 'sustainable fashion' is said to exist 'when all human interaction in the clothing supply chain work in good working conditions and are paid a fair living wage'..$^{50}$ It can refer to the working hours, working conditions, health and safety of the working environment, and the worker's pay. This term is often used interchangeably with the terms 'ethical' and 'sustainable' fashion. Evidently, there is significant overlap in definitions but also differences in the depth and rigour of key concepts. The lack of clarity behind commonly used terms has made the fashion industry extremely susceptible to companies 'greenwashing' or using misleading advertising to promote regular products as 'sustainable'. ${ }^{51}$

Due to the multiplicity of definitions and concepts, we argue for an approach to sustainable fashion that includes design, materials and processes that are, in a measurable way, environmentally and ethically conscious. Our definition also expands on the umbrella term 'ethical fashion' to include gender justice as an intrinsic and embedded part of a sustainable fashion industry. Such an approach, which encompasses women's and worker's rights simultaneously with a core focus on the environment and sustainability, allows us to reflect on the extent to which fast fashion companies' business models are focused on the promotion of consumption and production. ${ }^{52}$ As will be discussed in section IV, current practices run counter to SDG 12, which is focused on sustainable consumption and production.

Transitioning into a more sustainable fashion sector is not as simple as adopting new technological fixes at a future time. ${ }^{53}$ Unlike new sustainable technologies, the abuses of the rights of female workers in the sector have tangible solutions that can be addressed now. It is

\footnotetext{
${ }^{46}$ Valtteri Ranta and Ulla A Saari, 'Circular Economy: Enabling the Transition Towards Sustainable Consumption and Production' in Walter L Filho et al (eds.), Responsible Consumption and Production (New York: Springer, 2019 ), 1.

${ }^{47}$ Catrin Joergens, 'Ethical Fashion: Myth or Future Trend?' (2006) 10:3 Journal of Fashion Marketing and Management 360, 361.

48 Anders Haug and Jacob Busch, 'Towards an Ethical Fashion Framework' (2016) 20:3 Fashion Theory 317, 321.

${ }^{49} \mathrm{Ibid}, 321,326-327$. Haug and Busch name these nine actors as: market regulators, supplier regulators, consumers, mediators, designers, marketers, producers, suppliers, and workers.

50 Alana James and Bruce Montgomery, 'The Role of the Retailer in Socially Responsible Fashion Purchasing' in Subramanian S Muthu (ed.), Textiles and Clothing Sustainability: Sustainable Fashion and Consumption (Singapore: Springer, 2017) $1,3$.

${ }^{51}$ Lucia Gatti, Peter Seele and Lars Rademacher, 'Grey Zone in - Greenwash out. A Review of Greenwashing Research and Implications for the Voluntary-Mandatory Transition of CSR' (2019) 4 International Journal of Corporate Social Responsibility 6; Szerena Szabo and Jane Webster, 'Perceived Greenwashing: The Effects of Green Marketing on Environmental and Product Perceptions' (2020) 171 Journal of Business Ethics 719.

${ }^{52}$ Farley Gordon and Hill, note 37, 58.

${ }^{53}$ Kate Fletcher, Sustainable Fashion and Textiles: Design Journeys (London: Earthscan, 2008) 5. WRAP, 'Fibre to Fibre Recycling: An Economic \& Financial Sustainability Assessment' (2019), https://wrap.org.uk/sites/default/files/ 2021-04/F2F\%20Closed\%20Loop\%20Recycling\%20Report\%202018.pdf (accessed 2 June 2021) 4.
} 
for this reason that we seek to use the SDGs as a tool - albeit limited and flawed - to progress towards the goal of gender-just sustainable fashion.

\section{Viewing Fast Fashion Through the Sustainable Development Goals}

In this section we introduce the SDG framing of the fast fashion sector. There are clear links to be drawn between sustainable development and BHR frameworks. Moreover, as will be seen, despite the weaknesses of the SDGs, they show significant potential for creating stronger gender justice in the fashion sector. This section of the article concludes by elaborating on select legal responses to gender inequality and exploitation. While these national and regional laws have their limitations they can work alongside the SDGs and aid in filling gaps in a way that can facilitate greater gender justice in the fashion sector.

\section{Exploring the SDGs' Potential and Acknowledging Limitations}

The SDGs provide a useful framework for achieving a greater level of gender justice in the fast fashion sector, in particular when grounded in key BHR frameworks. The SDGs reference the United Nations Guiding Principles on Business and Human Rights (UNGPs) as a core framework, establishing an important link between the BHR and sustainable development agendas. In essence, this connection clarifies that respecting human rights should be the foundation of businesses' contribution to the SDGs.

Our article seeks to bring greater visibility to the potential of the SDGs to foster a more sustainable and gender-just approach to fashion. However, it is important to acknowledge the criticisms that have been directed to them: their drafting, their content, their measurement; and likely success. Here, we set out four of the most significant critiques. First, the SDGs' orthodox approach to economic growth is left unchallenged in their current design. ${ }^{54}$ The emphasis lies on increasing productivity and employment while social protection and redistributive policies are given secondary value. ${ }^{55}$ Moreover, insufficient attention is paid to the reality that (women's) unpaid care and domestic work sustain growth. ${ }^{56}$ We are, therefore, arguably at loggerheads, where economic growth depends on women's unpaid domestic care and reproductive work, and yet women's equality cannot be achieved without transforming care - to achieve its recognition, redistribution and reduction. ${ }^{57}$

Second, there is an evident power dynamic in the global policy-making arena, one that the SDGs do not entirely challenge. Some scholars critically note that while all states sat at the decision-making table to draft the 2030 Agenda, this cannot be equated to equal participation. ${ }^{58}$ Nonetheless, other scholars are less sceptical, seeing the SDGs as a truly 'global' agenda relevant for both high- and low-income countries. ${ }^{59}$

Third, and possibly most importantly, despite the advocacy efforts of the Women's Major Group in calling for the integration of a gender perspective in the SDGs, concerns remain

\footnotetext{
${ }^{54}$ Ramona Vijeyarasa, ‘Quantifying CEDAW: Concrete Tools for Enhancing Accountability for Women's Human Rights' (2021) 34 Harvard Human Rights Journal 37, 48.

${ }^{55}$ Valeria Esquivel, 'Power and the Sustainable Development Goals: A Feminist Analysis' (2016) 24:1 Gender and Development 9, 11.

56 Ibid.

${ }^{57}$ Akanksha A Marphatia and Rachel Moussié, 'A Question of Gender Justice: Exploring the Linkages between Women's Unpaid Care Work, Education, and Gender Equality’ (2013) 33:6 International Journal of Educational Development 585. Esquivel, note 55, 13-14.

${ }^{58}$ Esquivel, note 55, 13-14.

59 Sakiko Fukuda-Parr, 'From the Millennium Development Goals to the Sustainable Development Goals: Shifts in Purpose, Concept, and Politics of Global Goal Setting for Development' (2016) 24:1 Gender and Development 43, 44.
} 
that women's rights to development and the importance of women's agency have been treated as add-ons. ${ }^{60}$ Such an approach also tends to treat 'women' as a monolithic category. The extent of this problem becomes even more evident if we consider the relevance of women's multiple identities as workers in the garment sector. Inga Winkler and Meg Satterthwaite, for instance, highlight the SDGs' failure to call for data disaggregated on the basis of race or ethnicity. ${ }^{61}$ The broad SDG agenda obscures a holistic and nuanced understanding of women's experiences of poverty and marginalization and the barriers they face to full and equal participation in societies and economies. ${ }^{62}$ Participation in this sense is far from the reality of the majority of the most marginalized women.

Finally, there are limitations to what quantification can achieve in measuring progress on sustainable human development. Sally Engle Merry pointed out in extensive detail the limitations of quantification when it comes to human rights issues. ${ }^{63}$ Indicator-based projects frequently fail to give sufficient attention to cultural and social differences. Indicators may be ill defined, often without the most affected people involved in their design; and the resulting data easy to manipulate. ${ }^{64}$ However, as others have noted in response, including one of the co-authors of this article, if we want accountability - and of course we do - quantitative approaches may offer many advantages when compared with using resource-intensive qualitative approaches alone. ${ }^{65}$ The quantitative approach to accountability for development offered by the SDGs has much value to add in terms of comparability, within countries, over time, and across countries; and to motivate momentum, and monitor progress globally, towards these agreed ends.

While acknowledging these notable shortcomings in the framework of the SDGs, our approach in this article is to work within the existing system to identify what can be salvaged in the push for more equal and sustainable development. The potential is particularly notable if the SDGs are understood through a human rights lens. After all, it would be remiss to ignore the significant investments in and attention that the SDGs have garnered, from policy-makers, governments, businesses, and other stakeholders with key duties and responsibilities for ensuring that business activities are conducted in a manner that respects human rights. The SDGs have moved inequalities 'centre stage' with their aspirational language and rallying cry that no one will be left behind. ${ }^{66}$ Moreover, the undeniable relationship between business and human rights has already been well acknowledged ${ }^{67}$ We therefore are explicit in our acknowledgement of the SDGs' shortcomings while accepting the utility of working with the international policy instruments that occupy the space.

\footnotetext{
${ }^{60}$ Pieter Fourie and Colleen O'Manique, “'It Sells, But It Does Not Fly”: An Early Assessment of the 2030 Agenda for Sustainable Development' (2016) 59:1 Development 274, 276.

${ }^{61}$ Winkler and Satterthwaite, note 18.

${ }^{62}$ Esquivel, note 55, 16.

${ }^{63}$ Sally E Merry, The Seductions of Quantification: Measuring Human Rights, Gender Violence, and Sex Trafficking (Chicago: University of Chicago Press, 2016).

${ }^{64}$ Ibid; Gauthier de Beco, 'Human Rights Indicators for Assessing State Compliance with International Human Rights' (2008) 77:1-2 Nordic Journal of International Law 23; Sally E Merry, 'Measuring the World: Indicators, Human Rights, and Global Governance' (2011) 52:3 Current Anthropology S83.

${ }^{65}$ Jose-Miguel Bello y Villarino and Ramona Vijeyarasa, 'The Indicator Fad: How Quantifiable Measurement Can Work Hand-in-Hand with Human Rights - A Response to Sally Engle Merry's The Seductions of Quantification' (2018) 50:3 NYU Journal of International Law and Politics 985.

${ }^{66}$ Winkler and Satterthwaite, note 18, 1073.

${ }^{67}$ Rahim, note 6, 130; Christian Scheper, "“From Naming and Shaming to Knowing and Showing": Human Rights and the Power of Corporate Practice' (2015) 19:6 International Journal of Human Rights 737.
} 


\section{Key Business and Human Rights Developments Applicable to Addressing Gender Injustice in the Fashion Sector}

Here, we turn our attention to the legal environment in which the SDGs operate. Specifically, we use the limitations of these instruments but also their potential to develop a human rights-based understanding of the SDGs in the context of the fashion sector. The global shift towards the language of sustainability, inclusive growth and the UNGPs framework has been a fundamental step towards addressing the systemic inequality sustained by the fashion sector. These norms have inspired local, regional and global policy-making. ${ }^{68}$ One scholar even refers to the 'dizzying array of soft-law mechanisms such as voluntary guidelines, declarations, corporate codes of conduct and multi-stakeholder initiatives'. ${ }^{69}$

At the same time, the effectiveness of these norms is hindered by, among other things, the traditional mindsets of factory owners that focus on generating profits at all costs, government inefficiencies that undermine initiatives, and weak commitment on the part of the global buying firms and retailers when it comes to adhering to these policies. ${ }^{70}$ In the Association of South East Asian Nations (ASEAN) region, it has been suggested that the nature of national preferences combined with a general regional norm against interference are also undermining progress. ${ }^{71}$ Moreover, given the extent to which businesses are now attuned to 'human rights lingo', there is a notable risk in multi-national corporations 'know and show' efforts. ${ }^{72}$ What can result is the utilization of human rights language and frameworks in policies and reports by buyers in supply chains that act to disarm critiques without making fundamental changes to the context that led to these criticisms in the first place. $^{73}$

The purpose of this section is to place the SDGs in the context of other frameworks and instruments, particularly where they already incorporate a gender perspective, and consider how they can help operationalize the SDGs. Moreover, if we recognize existing gaps, the value in bringing together the SDGs and BHR frameworks to accelerate progress becomes even more evident.

\section{The UNGPs and the Gender Guidance}

The UNGPs provide 31 principles to act as a framework for greater accountability by businesses for abuses that take place in their operations and business relationships. ${ }^{74}$ Endorsed by the UN Human Rights Council in June 2011, they set the expectation that businesses respect human rights through undertaking 'human rights due diligence'. Among other things, the UNGPs call on states to offer guidance to businesses on how to effectively consider issues of 'gender, vulnerability and/or marginalization'75 and to support businesses to identify the heightened risks of sexual and gender-based violence. ${ }^{76}$

The UNGPs do not, however, systematically address issues of gender inequality, and have been criticized for their framing around 'vulnerability' and focus on sexual and genderbased violence. The UNGPs lack a call for 'gender-responsive human rights due diligence'

\footnotetext{
${ }^{68}$ Haug and Busch, note 48.

${ }^{69}$ Venkatesan, note 24, 635 .

${ }^{70}$ Rahim, note 6, 142.

${ }^{71}$ Charanpal S Bal and Kelly Gerard, 'ASEAN's Governance of Migrant Worker Rights' (2018) 39:4 Third World Quarterly 799.

72 Scheper, note 67, 739.

73 Ibid.

${ }^{74}$ Human Rights Council, 'Guiding Principles on Business and Human Rights: Implementing the United Nations "Protect, Respect and Remedy” Framework', A/HRC/17/31 (21 March 2011).

${ }^{75}$ Ibid, 8.

${ }^{76}$ Ibid, 10.
} 
that would render visible and respond to embedded gender norms, complex cultural biases, and power imbalances throughout supply chains. ${ }^{77}$ The requirements of truly genderresponsive human rights due diligence will vary from context to context, although some common aspects can be identified across industries, sectors and countries. Without this more rigorous, rights-based understanding of due diligence, we risk a dilution of corporations' responsibilities, which have largely been seen as voluntary, self-regulatory and limited in their understanding of gender-based abuses. ${ }^{78}$

In response to such critiques of the UNGPs on gender and women's rights, the UN Working Group on Business and Human Rights in 2019 developed a 'Gender Guidance' which provides a framework for states and businesses to take gender-responsive and gendertransformative measures in their interpretation and implementation of the UNGPs. ${ }^{79}$ Notably, the Gender Guidance makes several references to the fashion industry, for example, on supply chains, informal work, sexual harassment and modern slavery. ${ }^{80}$

Taking a gender-responsive approach to human rights due diligence can help to identify and address the different risks and vulnerabilities that female workers face. In response, some companies have begun to adopt policies that provide for equal pay and employment benefits and prohibit discrimination among full-time salaried employees. While a positive step, these initiatives ignore the reality of the vast majority of women workers in the sector who are informal and contract workers and therefore unable to benefit. ${ }^{81}$ Meaningful stakeholder engagement is also key, as reflected in SDG 5.5 on ensuring women's full and equal participation. ${ }^{82}$ Although there are clear limitations to what corporations alone can do to challenge systemic inequality, they must acknowledge its existence and take concrete steps to ensure that they do not perpetuate or benefit from it. ${ }^{83}$

Despite their lack of real engagement with gendered human rights abuses, ten years after their adoption, the UNGPs have established themselves as a 'normative platform' that has aided widespread convergence of national and international regulatory initiatives. ${ }^{84}$ This includes the incorporation of the UNGPs into legal and policy instruments including the 2011 Communication on Corporate Social Responsibility (CSR) and the European Union (EU) Directive No. 2014/95 on non-financial reporting. While the call for more hard law such as a treaty addressing the human rights obligations of businesses - continues, the potential and value in the UNGPs in guiding soft law and national practice has been acknowledged as a crucial step in laying the foundations for a more ambitious, legally binding approach in the long term. ${ }^{85}$

\footnotetext{
${ }^{77}$ Bourke Martignoni and Umlas, note 19; Vijeyarasa, note 10.

${ }^{78}$ Savitri W E Goonesekere, 'The Indivisibility of Rights and Substantive Equality for Women' in Niamh Reilly (ed.), International Human Rights of Women (Singapore: Springer Nature, 2019) 39, 55.

${ }^{79}$ Human Rights Council, 'Gender Dimensions of the Guiding Principles of Business and Human Rights' A/HRC/41/43 (23 May 2019) 6.

${ }^{80}$ Ibid.

${ }^{81}$ Khema Sharma, 'Role of Women in Informal Sector in India' (2012) 4:1 IOSR Journal of Humanities and Social Science 29, 32.

${ }^{82}$ United Nations Development Programme, 'The SDGs in Action', https://www.undp.org/content/undp/en/ home/sustainable-development-goals/ (accessed 2 June 2021), sec 5.5.

83 Bourke-Martignoni and Umlas, note 19, 8.

${ }^{84}$ See Human Rights Council, 'Guiding Principles on Business and Human Rights at 10: Taking Stock of the First Decade', A/HRC/47/39 (22 April 2021); OHCHR, 'The Next Decade of Business and Human Rights', https:// www.ohchr.org/EN/Issues/Business/Pages/UNGPsBizHRsnext10.aspx (accessed 16 September 2021).

${ }^{85}$ Marta Bordignon, 'State Commitment in Implementing the UNGPs and the Emerging Regime of National Action Plans: A Comparative Analysis' (2016) 10 Human Rights and International Legal Discourse 117; Daniel Augenstein, Mark Dawson and Pierre Thielbörger, 'The UNGPs in the European Union: The Open Coordination of Business and Human Rights?' (2018) 3:1 Business and Human Rights Journal 1, 22; Claire M O’Brien, 'Transcending the Binary: Linking
} 


\section{'Modern Slavery' Regulations}

Several jurisdictions in recent years have attempted to introduce regulations to identify, address and eradicate exploitation in supply chains. ${ }^{86}$ Many of these 'modern slavery' regulations specifically include the supply chains of major fashion businesses within their scope; however, few have done better than the SDGs in integrating a gender-responsive approach. ${ }^{87}$

In 2015, the United Kingdom (UK) enacted its Modern Slavery Act, creating an obligation on corporations with a turnover of more than UK£36 million - around 13,000 companies - to report on the steps they have taken to identify instances of slavery and trafficking in their supply chains or in their own businesses or to disclose a failure to undertake such due diligence. ${ }^{88}$ Meanwhile, in 2016, the Netherlands introduced a Child Labour Due Diligence Law (Wet Zorgplicht Kinderarbeid) which took effect from 1 January $2020^{89}$ while France adopted a 'duty of vigilance' law in February 2017. ${ }^{90}$ The French law establishes concrete obligations to prevent exploitation within the supply chains of large multi-national firms carrying out a significant part of their activity in France. ${ }^{91}$ In the EU, the Non-Financial Reporting Directive requires around 8,000 large European companies to disclose their policies, risks and responses related to respect for human rights. ${ }^{92}$

However, arguably none of these laws could be considered good practice global examples from a gender perspective, particularly for the lack of an explicit call for the adoption of gender-responsive due diligence processes and the collection of gender-disaggregated data. ${ }^{93}$ A good practice law would also address environmental damage alongside human rights abuses, as the French law does. ${ }^{94}$

One final limitation of these 'modern slavery' regulations is the tendency to outsource due diligence and reporting to third parties. What often results is a 'template' approach to reporting. ${ }^{95}$ Enforcement of these laws and transparency are challenging, with the legislation only as good as the actionable intelligence that can be brought to law enforcement. ${ }^{96}$ These limitations are exacerbated by the reality that few modern slavery laws impose appropriate penalties. ${ }^{97}$

Hard and Soft Law Through a UNGPS-Based Framework Convention' (2020) 114 American Journal of International Law 186.

${ }^{86}$ Ramona Vijeyarasa, 'A Missed Opportunity: How Australia Failed to Make its Modern Slavery Act a Good Practice Global Example’ (2019) 40:3 Adelaide Law Review 857.

${ }^{87}$ Ibid, 861, 865 .

${ }^{88}$ Modern Slavery Act 2015 (UK), sec 54.

${ }^{89}$ Initiatiefvoorstel Wet Zorgplicht Kinderarbeid, Law No. 34506, 24 June 2016 (NL).

${ }^{90}$ Loi Relative au Devoir de Vigilance des Sociétés Mères et Des Entreprises Donneuses d'Ordre, Loi No. 2017-399, 27 March 2017 (FR).

${ }^{91}$ Stéphanie Poirot, 'Devoir de Vigilance des Entreprises: Entre Hard et Soft Law, Une Réponse au "Social Washing"?', The Conversation (24 May 2018), http://theconversation.com/devoir-de-vigilance-des-entreprisesentre-hard-et-soft-law-une-reponse-au-social-washing-96451 (accessed 2 June 2021). The law came into effect in March 2017, but with the proposed civil penalties for violating corporations struck down following a decision of the Constitutional Council. See Décision No. 2017-750 DC, Conseil Constitutionnel (23 March 2017).

92 'Directive 2014/95/EU of the European Parliament and of the Council of 22 October 2014 Amending Directive 2013/34/EU as Regards Disclosure of Non-Financial and Diversity Information by Certain Large Undertakings and Groups Text with EEA Relevance', 32014L0095, 22 October 2014, 330.

${ }^{93}$ Vijeyarasa, note 86, 865.

94 Ibid.

95 Safia Minney, Slave to Fashion (Oxford: New Internationalist, 2018) 16.

${ }^{96}$ Ibid, 24.

${ }^{97}$ Gary Craig, 'The UK's Modern Slavery Legislation: An Early Assessment of Progress' (2017) 5:2 Social Inclusion 16,22 . 


\section{International Labour Organization Convention on the Elimination of Violence and}

Harassment in the World of Work (2019)

In 2019, the International Labour Organization (ILO) adopted the landmark Convention on the Elimination of Violence and Harassment in the World of Work. ${ }^{98}$ It adopts a broad definition of violence and harassment while calling on governments to take steps to protect workers, with particular acknowledgement of women's greater exposure to exploitation. Importantly, it applies in both the formal and informal economies and sets out a wide scope in terms of the spaces that are brought within the bounds of the Convention. ${ }^{99}$ This includes the workplace itself, but also spaces of rest, and places where workers use sanitary, changing and washing facilities as well as the commute to and from work. ${ }^{100}$

The Convention has the potential to protect millions of workers who are otherwise marginalized and at risk in insecure, low paid, unsafe jobs. ${ }^{101}$ Explicitly acknowledging the disproportionate effect of violence on women at work, it identifies the need for a gender-responsive and intersectional approach that includes groups such as women migrant workers who may need particular protection. ${ }^{102}$ Importantly, the Convention recognizes that interventions to address harassment and violence must not result in women's exclusion from the workplace or other forms of retaliation. ${ }^{103}$ Beyond the fact that there is significantly greater visibility today than ever before to the issue of genderbased violence, ${ }^{104}$ the Convention's influence may be enhanced through the SDG 5's parallel attention to gender-based violence as one of the most pervasive human rights violations in the world today. ${ }^{105}$

\section{Achieving Fashion Justice Through the SDGs: What Will it Take?}

This article argues for the importance of understanding sustainability and gender justice as intimately connected. In this section, we offer a perspective on how the SDGs can be advanced, in the context of the fashion sector, to promote sustainable outcomes that are gender-just. See Table 1 for a list of the 17 SDGs. ${ }^{106}$

Many of the 17 SDGs and their 244 indicators are applicable to the fashion sector. Given the comprehensive nature of the SDGs and related indicators, this exercise is naturally illustrative rather than exhaustive. Nonetheless, the most pertinent goals and indicators have been prioritized to offer readers a lens into the areas with the most potential to advance progress. Goal 5, focused on the achievement of gender equality, is one of the most obvious in understanding fast fashion from a gender perspective, but many other goals and targets prove relevant.

\footnotetext{
${ }^{98}$ Makbule Sahan, 'The First International Standard on Violence and Harassment in the World of Work' (2020) 5:2 Business and Human Rights Journal 289.

${ }_{99}$ Convention Concerning the Elimination of Violence and Harassment in the World of Work, ILO Convention No. 190 (adopted on 21 June 2019, entered into force on 25 June 2019), sec II, art 2.

${ }^{100} \mathrm{Ibid}$, art 3(f). See also Sahan, note 98, 292.

101 Sahan, note 98, 89-90.

102 Convention on the Elimination of Violence and Harassment in the World of Work, note 99, art 6.

103 Ibid, art 10(h).

${ }^{104}$ Ramona Vijeyarasa, 'CEDAW's General Recommendation No. 35: A Quarter of a Century of Evolutionary Approaches to Violence against Women' (2020) 19:2 Journal of Human Rights 153.

${ }^{105}$ Committee on the Elimination of Discrimination against Women, 'General Recommendation No. 35 on Gender-Based Violence against Women, Updating General Recommendation No. 19', CEDAW/C/GC/35 (13 July 2017) paras 4, 6. See also ibid.

${ }^{106}$ United Nations Development Programme, note 82.
} 
Table I. The 17 Sustainable Development Goals

\begin{tabular}{|c|c|}
\hline Goal I & End poverty in all its forms everywhere \\
\hline Goal 2 & End hunger, achieve food security and improved nutrition and promote sustainable agriculture \\
\hline Goal 3 & Ensure healthy lives and promote well-being for all at all ages \\
\hline Goal 4 & $\begin{array}{l}\text { Ensure inclusive and equitable quality education and promote lifelong learning opportunities } \\
\text { for all }\end{array}$ \\
\hline Goal 5 & Achieve gender equality and empower all women and girls \\
\hline Goal 6 & Ensure availability and sustainable management of water and sanitation for all \\
\hline Goal 7 & Ensure access to affordable, reliable, sustainable and modern energy for all \\
\hline Goal 8 & $\begin{array}{l}\text { Promote sustained, inclusive and sustainable economic growth, full and productive } \\
\text { employment and decent work for all }\end{array}$ \\
\hline Goal 9 & $\begin{array}{l}\text { Build resilient infrastructure, promote inclusive and sustainable industrialization and foster } \\
\text { innovation }\end{array}$ \\
\hline Goal 10 & Reduce inequality within and among countries \\
\hline Goal II & Make cities and human settlements inclusive, safe, resilient and sustainable \\
\hline Goal 12 & Ensure sustainable consumption and production patterns \\
\hline Goal 13 & Take urgent action to combat climate change and its impacts \\
\hline Goal I4 & $\begin{array}{l}\text { Conserve and sustainably use the oceans, seas and marine resources for sustainable } \\
\text { development }\end{array}$ \\
\hline Goal 15 & $\begin{array}{l}\text { Protect, restore and promote sustainable use of terrestrial ecosystems, sustainably manage } \\
\text { forests, combat desertification, and halt and reverse land degradation and halt biodiversity } \\
\text { loss }\end{array}$ \\
\hline Goal 16 & $\begin{array}{l}\text { Promote peaceful and inclusive societies for sustainable development, provide access to } \\
\text { justice for all and build effective, accountable and inclusive institutions at all levels }\end{array}$ \\
\hline Goal 17 & $\begin{array}{l}\text { Strengthen the means of implementation and revitalize the global partnership for sustainable } \\
\text { development }\end{array}$ \\
\hline
\end{tabular}

\section{Six Requirements for Gender-Just and Sustainable Fashion}

Below we set out the six key requirements that we have identified as essential to enabling the SDGs to fulfil their potential in advancing gender justice in the fashion sector. This list draws on the most pertinent SDGs and their targets when it comes to accountability for sustainable and gender-just fashion. The requirements capture the multi-dimensional experiences of women workers, seek to respond to and challenge the notion of the 'monolithic' women worker by recognizing multiple and intersecting identities, and offer a broader understanding of accountability beyond a narrow focus on the workplace.

\section{Responsible Consumption}

Responsible consumption is potentially the fundamental step towards sustainable and gender-just fashion. Target 12.2.1 of SDG 12 on Responsible Consumption and Production 
entails capturing the material footprint per capita and per GDP. Material footprint refers to the total amount of raw materials extracted to meet final consumption demands. ${ }^{107}$

In the context of sustainable fashion, this target is linked to the circular economy and the elimination of the 'throwaway' culture that the global fast fashion business model has been built on. ${ }^{108}$ Estimates suggest that 80 billion garments are produced every year. ${ }^{109}$ This excess cycle of production and consumption has an undeniable environmental toll. Some estimates suggest that the fashion industry is responsible for 10 per cent of global carbon emissions and 20 per cent of global waste water. ${ }^{110}$ Unsurprisingly, quantifying the effect of such production on the working conditions of workers is a difficult task.

Sustainable consumption from the demand side is therefore a key part of the response. Research shows that consumer-level compassion-based interventions can raise awareness about the dangerous and unfair conditions women fashion workers face and alter consumption patterns to become more sustainable. ${ }^{111}$ Other studies have demonstrated that while ethics will not trump certain considerations shaping fashion decision-making - cost, appearance, durability - they are certainly a consideration. ${ }^{112}$ Consumers need persuading to make human rights-based decisions, in the same way that they are persuaded by brand, quality, price and product characteristics. ${ }^{113}$ Awareness about SDG 8 that cements the links between consumption and workers' rights can pursuade consumers in adopting sustainable practices, which in turn can incentivize fashion brands to prioritize circular economy models.

\section{Tax as Gender-Just}

Domestic resource mobilization is essential for sustainable development, raising important questions about how countries can finance this development. Taxation as a source of government revenue can make an essential contribution to a country, community and infrastructure where workers are based. By acknowledging the relationship between corporate tax, public revenue raising, public spending and public services, we can see how a genderjust approach to the fashion sector can help to address some of the social and economic inequalities women face. Moreover, given that, to date, the human rights framework has only made limited progress in addressing the issue of justice and tax distribution in a meaningful way, measuring progress against the SDGs could catalyse new initiatives in this area.

In terms of a gender-just approach, it is important to acknowledge how the absence of taxes to support infrastructure and social protection is likely to affect women more than men. In Asia, for example, the ILO has reported that women do 4.1 times more unpaid care work than men. ${ }^{114}$ Women's unpaid contribution to social reproduction remains too often

\footnotetext{
107 Roser Ritchie and Oritz-Ospina Mispy, 'Goal 12: Ensure Responsible Consumption and Production Patterns', SDG-Tracker.Org (2018), https://sdg-tracker.org/sustainable-consumption-production (accessed 6 August 2021).

${ }^{108}$ Ranta and Saari, note 46,11. ENDEVR, 'The True Cost: Who Pays the Real Price for YOUR Clothes | Investigative Documentary', https://www.youtube.com/watch?v=5-0zHqYGnlo (accessed 6 August 2021).

109 ENDEVR, note 108.

${ }^{110}$ United Nations Economic Commission for Europe, 'UN Alliance Aims to Put Fashion on Path to Sustainability', https://www.unece.org/info/media/presscurrent-press-h/forestry-and-timber/2018/un-alliance-aims-to-putfashion-on-path-to-sustainability/doc.html (accessed 2 June 2021).

111 Sonia M Geiger and Johannes Keller, 'Shopping for Clothes and Sensitivity to the Suffering of Others: The Role of Compassion and Values in Sustainable Fashion Consumption' (2018) 50 Environment and Behavior 1119.

112 Louise Lundblad and Iain A Davies, 'The Values and Motivations behind Sustainable Fashion Consumption' (2016) 15:2 Journal of Consumer Behaviour 149.

${ }^{113}$ Ranta and Saari, note 46, 10.

${ }^{114}$ International Labour Organization, 'ILO: Women Do 4 Times More Unpaid Care Work than Men in Asia and the Pacific', http://www.ilo.org/asia/media-centre/news/WCMS_633284/lang-en/index.htm (accessed 2 June 2021). Caroline C Perez, Invisible Women: Data Bias in a World Designed for Men (London: Random House, 2019) 29.
} 
invisible and comprehensive social protection schemes are under-funded by governments. ${ }^{115}$ This unequal share of care work must be contextualized in the reality that garment workers are frequently migrant women, who have moved to industrial zones or export processing zones to work in factories. ${ }^{116}$ This model of employment often involves leaving behind children to be cared for by other (usually female) family members, where they too may lack support. Relevantly, SDG Target 5.4.1 tracks the proportion of time spent on unpaid domestic and care work, by sex, age and location. The recognition of unpaid work in the SDGs should be used to draw attention to the reality that gendered labour currently sustains the global economy in ways that frequently undermine women's rights. ${ }^{117}$

In response, we draw direct lines between the potential for a rigorous and monitored system of corporate taxation and increased government resources for the benefit of women workers. This might include safe public transport, street lighting and childcare. The issue of women's mobility, and barriers to safe access caused by, for example, gender-based violence, might be resolved in part if transport services catering exclusively to women were introduced. Without such reforms, the prospects for many women who live in areas characterized by poor physical accessibility and inadequate transport service provision will remain limited. Governments must guarantee social protection for women workers to also address the burden of social reproductive work, and its consequences, typically borne by women. ${ }^{118}$ The implications in terms of intergenerational transfers of poverty are evident.

This issue raises a regulatory loophole whereby companies such as H\&M often do not own production factories, but rather, define themselves as buying their products from 'independent suppliers'. In the company's own words, in light of these 'local representative procurement offices', 'H\&M accordingly has no trading activity that creates business income and is therefore not in a position to pay corporate income tax in the countries where the representative offices are located'. ${ }^{119}$ Fashion companies have been criticized for incorporating in countries that are tax havens to avoid paying taxes. ${ }^{120}$ Zara's parent company Inditex was the subject of extensive critique from civil society organizations

\footnotetext{
${ }^{115}$ Shirin M Rai and Beth Goldblatt, 'Introduction to the Themed Section: Law, Harm and Depletion Through Social Reproduction' (2020) 3:2 European Journal of Politics and Gender 171.

116 Tanja Bastia, 'From Mining to Garment Workshops: Bolivian Migrants in Buenos Aires' (2007) 33:4 Journal of Ethnic and Migration Studies 655; Jenny W L Chan, 'Chinese Women Workers Organize in the Export Zone' (2006) 15:1 New Labor Forum 19; Nick J Freeman, Whither Myanmar's Garment Sector? (Singapore: ISEAS Publishing, 2019); Ruchira T Naved, Margaret Newby and Sajeda Amin, 'The Effects of Migration and Work on Marriage of Female Garment Workers in Bangladesh' (2001) 7:2 International Journal of Population Geography 91; Kasumi Nishigaya, 'Female Garment Factory Workers in Cambodia: Migration, Sex Work and HIV/AIDS' (2002) 35:4 Women Health 27.

117 Beth Goldblatt and Shirin Rai, 'Remedying Depletion Through Social Reproduction: A Critical Engagement with the United Nations' Business and Human Rights Framework' (2020) 3:2 European Journal of Politics and Gender 185.

118 Ahmed, note 15.

119 H\&M Group, 'H\&M’s Tax Policy in Brief', https://hmgroup.com/about-us/corporate-governance/policies/ (accessed 2 June 2021).

${ }^{120}$ Alex Crumbie, 'Clothing Companies and Tax Havens', Ethical Consumer (5 September 2019), https://www.ethi calconsumer.org/fashion-clothing/clothing-companies-tax-havens (accessed 2 June 2021); Tax Justice Network, 'New Ranking Reveals Corporate Tax Havens Behind Breakdown of Global Corporate Tax System; Toll of UK's Tax War Exposed', Tax Justice Network Blog (28 May 2019), https://www.taxjustice.net/2019/05/28/new-rankingreveals-corporate-tax-havens-behind-breakdown-of-global-corporate-tax-system-toll-of-uks-tax-war-exposed/ (accessed 2 June 2021).
} 
and in turn shut down its operations in Ireland after using its Irish-based ITX Fashion subsidiary to avoid paying EU€585 million in taxes during the period 2011-2014. ${ }^{121}$

A key gap therefore is the return by multinational companies - through taxation - to the countries in which they operate, that could otherwise contribute to an increase in available resources for the producing country to spend on public infrastructure - everything from roads and lighting, public housing, and healthcare services in close proximity to factories; or childcare facilities, either near factories or in home-towns where children of migrant women are left in the care of families, and guaranteed social protection. ${ }^{122}$ The SDGs provide an approach that connects these issues of gendered social reproduction and garment workers' rights and offer a framework to address the need for attention to corporate taxation in the fashion sector.

\section{Voice as Gender-Just}

Women make up the majority of garment workers, but their voice and participation in corporate and government decision-making remain marginal. The low levels of women's representation on boards and in leadership roles in major corporations is one manifestation of gendered power relations within business activities and Target 5.5.2 of the SDGs tracks the proportion of women in managerial positions. ${ }^{123}$ It is important, however, to shift away from using women's participation at a senior level in businesses as a proxy for equality of representation in the workplace in general.

This problem becomes particularly stark when we consider the variety of spaces where women work and where they are most marginalized from workplace decision-making. In this respect, SDG 8 brings visibility to the absence of voice for some of the world's most marginalized workers. SDG 8.8 seeks to protect the labour rights and working environments of, among others, migrant workers and women migrants in particular. Trade unions have improved representation, but the approach of these organizations to gender equality has often been piecemeal and many women fashion workers remain un-unionized. This is one factor, intertwined with fear of retaliation, that leads to under-reporting of human rights abuses in the workplace. ${ }^{124}$ In light of this, women's rights organizations have taken steps to mobilize for themselves to advocate for improvements to working conditions. ${ }^{125}$

Home-based workers in the fashion industry are a particularly invisible category. Some female workers prefer or require the flexibility of home-based work, including because they face cultural obstacles to working outside the home, but this kind of work is less monitored, often involves piece-rate pay, and precludes workers from organizing, putting them at risk

\footnotetext{
${ }^{121}$ Marc Tataret, Tax Shopping: Exploring Zara's Tax Avoidance Business, (Greens/EFA Group, 2016), https://www.glo baltaxjustice.org/sites/default/files/TAX_SHOPPING_-_Greens-EFA_report_on_Inditex_-_08_12_2016.pdf (accessed 2 June 2021).

${ }^{122}$ Studies of Bangladesh and Cambodia discuss a range of infrastructure needs. These may differ, depending on whether children of migrant women workers remain in their care or in the care of families at the point of origin. See Mohammed M M Chowdhury, Nazamul Hoque and Jonayed Kabir, 'Work-Life Balance of Female Garment Workers in Bangladesh: An Imperial Investigation' (2015) 15:7 Global Journal of Management and Business Research 18; Fiona H McKay and Hayley J McKenzie, 'Life Outside the Garment Factories: The Lived Experiences of Cambodian Women Garment Factory Workers' (2020) 16:4 International Journal of Migration, Health and Social Care 415.

${ }^{123}$ Vijeyarasa, note 10, 86.

${ }^{124}$ Kate Hodal, 'Slavery and Trafficking Continue in Thai Fishing Industry, Claim Activists', The Guardian (25 February 2016), https://www.theguardian.com/global-development/2016/feb/25/slavery-trafficking-thaifishing-industry-environmental-justice-foundation (accessed 2 June 2021).

${ }^{125}$ Marina Prieto-Carrón, 'Bringing Resistance to the Conceptual Center: Threats to Social Reproduction and Feminist Activism in Nicaraguan Commodity Chains' in Wilma A Dunaway (ed.), Gendered Commodity Chains: Seeing Women's Work and Households in Global Production (Stanford: Stanford University Press, 2013) 225.
} 
of lower pay and poorer working conditions. ${ }^{126}$ Unlike factory workers, many suffer from fewer choices, limited bargaining power, and no mobility. ${ }^{127}$ Their employment is often informal and outsourced, creating a low-cost flexible workforce that is easily exploited. ${ }^{128}$

Shifting the business accountability model therefore requires creating avenues for homebased fashion workers to safely report abuse. In this sense, the landmark Convention on the Elimination of Violence and Harassment in the World of Work (see above), is essential for the achievement of the SDGs. Removing some of the barriers to reporting that are an inherent condition of home-based work must also be prioritized. This includes recognizing some of the very context-specific aspects of such home-based work where a female worker's only contact with the buyer may be through a male relative, against whom they may wield limited power.

\section{Living Wage as Gender-Just}

There is an indisputable relationship between the price of clothing, profit produced, and the wages set by corporations. Fashion manufacturing is considered the classic example of a 'buyer-driven chain' where retailers hold all the power when they negotiate with factories. ${ }^{129}$ Factory owners are often only legally obliged to pay the minimum wage. ${ }^{130}$ Moreover, to offer competitive prices, factories often necessarily push workers harder and give them unrealistic deadlines. If workers fail to meet deadlines, they frequently suffer wage penalties. In the words of Jennifer Rosenbaun, USA Director of the Global Labour Justice: 'We must understand gender-based violence as an outcome of the global supply chain structure. H\&M and Gap's fast fashion supply chain model creates unreasonable production targets and underbid contracts, resulting in women working underpaid overtime and working very fast under extreme pressure. ${ }^{131}$ By contrast, the Global Living Wage Coalition defines a living wage as: ${ }^{132}$

The remuneration received for a standard workweek by a worker in a particular place sufficient to afford a decent standard of living for the worker and her or his family. Elements of a decent standard of living include food, water, housing, education, health care, transportation, clothing, and other essential needs including provision for unexpected events.

The goal of shifting beyond mere employment to a living wage is closely related to SDG 8: the promotion of sustained, inclusive and sustainable economic growth, full and productive employment, and decent work for all. Target 8.5 seeks to achieve the full and productive employment and decent work for all women and men, including for young people, and people with disabilities. The ending of poverty in all forms for everyone (SDG 1) includes essential targets related to social security (Target 1.3). Pertinent to the fashion sector, this target brings within its scope social protection floors that include maternity payments, unemployment and disability insurance.

\footnotetext{
${ }^{126}$ Bourke-Martignoni and Umlas, note 19, 33.

${ }^{127}$ Minney, note 95, 43.

${ }^{128}$ Human Rights Council, note 84, 51.

${ }^{129}$ Gary Gereffi and Miguel Korzeniewicz, Commodity Chains and Global Capitalism (Connecticut: Praeger Publishers, 1994).

${ }^{130}$ Minney, note 95, 45.

${ }^{131}$ Kate Hodal, 'Abuse is Daily Reality for Female Garment Workers for Gap and H\&M, Says Report' The Guardian (5 June 2018), https://www.theguardian.com/global-development/2018/jun/05/female-garment-workers-gaphm-south-asia (accessed 16 September 2021).

132 Global Living Wage Coalition, 'What is a Living Wage?' https://www.globallivingwage.org/about/what-is-aliving-wage/ (accessed 2 June 2021).
} 
As such, gender justice must extend to a broader corporate and government understanding of the living wage. It is important to also situate the worker in the community in which they live and work. Local economies are often dynamic and adapt to the change in wages. In Cambodia, the inability of the living wage to keep up with rising rent has catalysed mass protests among garment workers. ${ }^{133}$ If increases in the living wage are simply absorbed by a handful of property owners and vendors, it fails to benefit garment workers. These realities must also be acknowledged and are encapsulated in a more community-based understanding of the worker's experiences as discussed in the following section.

\section{Community as Gender-Just}

SDG 6 seeks the availability and sustainable management of water and sanitation for all. Women and girls are specifically acknowledged as being forced into situations where they are put at risk. Target 6.2.1 seeks to document the proportion of the population using safely managed sanitation services including handwashing facilities with soap and water. The need for planned and well-managed migration policies is also acknowledged in Target 10.7 while safe and affordable housing is also a target under 11.1. These targets highlight some of the basic limitations of the garment sector for many workers, particularly when we acknowledge the experience of workers - many of whom are internal migrants - off the factory floor.

Research evidences the close links between women's experiences within and outside of factories. In garment producing countries like Cambodia and Bangladesh, women workers are frequently migrants from rural and remote communities who have travelled to the capital. ${ }^{134}$ Inadequate policing, overcrowded rental areas, poor hygiene and sanitation, poor lighting, and the distance between rental rooms and toilets have been found to increase the risk women face of violence. ${ }^{135}$ Given the isolation many women migrants face when moving into areas where garment sector work is available, ${ }^{136}$ promoting access to reproductive health services and knowledge about access to reproductive health services is equally important. Migrant women may also be subject to racial discrimination and are at greater risk of exploitation when they lack adequate documentation. ${ }^{137}$

SDG 6 therefore offers much value in bringing visibility and a more comprehensive understanding of the living and working conditions of women in the sector. These experiences, both on and off the factory floor, highlight the significance of the broad scope of ILO Convention 190 that encompasses violence and harassment 'occurring in the course of, linked with or arising out of work', including during commutes and at employer-provided accommodation. ${ }^{138}$

\section{Accountability as Gender-Just}

The need to guarantee women access to effective remedies when confronted with rights abuses is a core human rights principle. Women's access to justice is the subject of the Committee on the Elimination of Discrimination against Women's General Recommendation

\footnotetext{
${ }^{133}$ David Sen, 'Phnom Penh Garment Workers Protest Hike in Rent', Khmer Times (22 April 2019), https:// www.khmertimeskh.com/50596897/garment-workers-protest-hike-in-rent/ (accessed 2 June 2021).

${ }^{134}$ Ahmed, note 15; Nishigaya, note 116.

135 Alice Taylor, Women and the City: Examining the Gendered Impacts of Violence and Urbanisation (Johannesburg: ActionAid International, 2011) 30.

${ }^{136}$ Nicola Mucci et al, 'Migrant Workers and Psychological Health: A Systematic Review' (2020) 12:1 Sustainability 120; Bin Wu and Jackie Sheehan, 'Globalization and Vulnerability of Chinese Migrant Workers in Italy: Empirical Evidence on Working Conditions and Their Consequences' (2011) 20:68 Journal of Contemporary China 135.

${ }^{137}$ Minney, note 95, 43.

${ }^{138}$ Convention on the Elimination of Violence and Harassment in the World of Work, note 99, art 3.
} 
No. 33. ${ }^{139}$ Yet formal justice, let alone a gender-sensitive justice system that is independent, impartial, credible, and acts with integrity in the fight against impunity, ${ }^{140}$ may be far from reach for many women workers.

Gender-based violence against women within the workplace as well as off the factory floor - especially in communities surrounding the factories - needs to be a central concern for the fashion sector. Target 5.2.2 seeks a reduction in the portion of women suffering various forms of violence - physical, sexual or psychological - by individuals other than their partners. Research shows the extent to which women workers have to travel, often on unlit streets, to and from their housing to work, facing the risk of harassment, theft, and forms of sexual violence. ${ }^{141}$

Subcontracting, where a factory sends a worker to another factory without the knowledge of the buying fashion brand, is a challenge in supply chain transparency and heightens exposure to exploitation. ${ }^{142}$ In such contexts of subcontracting, the fast fashion company (the buyer) shifts accountability to the supplier (the factory), who in turn is able to blame the subcontractor for workers' rights abuses. Ultimately, the subcontractor blames the individual worker. ${ }^{143}$ There is little consequence for this way of operating and consequently, the practice continues with impunity.

Moreover, numerous barriers - financial and linguistic, as well as fear - may undermine attempts by workers to seek re-dress for the failure of employers to pay a living wage or for abuses of workers' rights to freely join a trade union and exercise their freedom of expression or assembly. This sixth prong in our framework - access to remedies for affected workers - calls for an expansive understanding of justice, and an inclusive approach to the injustices that need to be remedied. SDG 16 addresses the promotion of just, peaceful and inclusive societies. Target 16.1, to 'significantly reduce all forms of violence and related death rates everywhere' creates an entry point to bring visibility to the realities of genderbased violence for workers. The garment sector has a key part to play in addressing violence at work for women garment workers and creating an enabling environment for genderresponsive due diligence to monitor incidence of violence and respond where cases are identified, both in and beyond factories. ${ }^{144}$ At the same time, Target 16.3, which includes '[ensuring] equal access to justice for all', is essential to ensure an approach to justice that goes beyond the injured gendered body and guarantees redress for a range of human rights abuses, including unequal pay and gender-based discrimination. ${ }^{145}$

\section{The Way Forward}

The SDGs are far from perfect. Most fundamental among their limitations is their failure to challenge structural power relations among nations and businesses that are otherwise intended to be equally governed by these goals and targets. They risk reinforcing stereotypes that have underpinned at times false distinctions between the Global North and Global South and clouded deep inequalities that exist within countries. A holistic and nuanced understanding of women's experiences of poverty and marginalization is often lost in

\footnotetext{
${ }^{139}$ Committee on the Elimination of Discrimination against Women, 'General Recommendation No. 33 on Women's Access to Justice', CEDAW/C/GC/33 (23 July 2015).

140 Ibid, para 1.

141 Taylor, note 135 .

${ }^{142}$ Minney, note 95, 22.

${ }^{143}$ Hayley Mlotek, 'Fast Fashion at the End of the World', The New Republic (19 December 2019), https:// newrepublic.com/article/156065/fast-fashion-end-world (accessed 2 June 2021).

144 Vijeyarasa, note 10.

145 Ratna Kapur, 'Brutalized Bodies and Sexy Dressing on the Indian Street' (2014) 40:1 Signs: Journal of Women in Culture and Society 9.
} 
pursuit of aggregation, whereas disaggregation is essential to challenge the notion of the monolithic woman and to bring out the intersectional experiences of those who are most marginalized and excluded.

At the same time, the SDGs are a highly visible policy instrument that resonates beyond the walls of the UN. Their uptake by many policy-makers, civil society and the media should come as no surprise and their limitations should not overshadow the potential of the SDGs as a framework for enhancing a gender-just and sustainable response to the fashion industry. Perhaps unexpectedly, the SDGs have become a way to benchmark fashion companies' commitments to sustainability and worker's rights. The SDGs' user-friendliness among civil society is a big win. Non-governmental organizations whose work lies in auditing the impact of fashion companies, including on women workers, and the investigative journalists working to challenge fast fashion, have a capacity to shine a light on problems such as inadequate wages, unpaid or underpaid overtime, and the inadequacy of working conditions, through the lens of the SDGs in a way that may resonate more strongly with policy-makers. It is rare for a global policy instrument to be as accessible as the SDGs and its targets.

At the same time, while accessible, many might consider the 17 goals and 244 indicators overwhelming. What we have sought to achieve in this paper is to lay a clear pathway to maximize the SDG's potential to promote a more sustainable and gender-just fashion sector. The SDGs may seem counterintuitive to the economic interests of fashion companies. Reliance on self-regulation in the form of annual reports also has its limits. ${ }^{146}$ Acknowledging these limits, we have sought to demonstrate the ways in which the SDGs can promote sustainable outcomes that are just for women. Arguably, greater buy-in is needed to operationalize the SDGs' potential, such as the targets that call for consumer education on their contribution to the material footprint as well as the need for governments to develop effective corporate taxation systems alongside social protection floors. Moreover, the more powerful actors in supply chains need to come on board in order to use their bargaining power to negotiate a more holistic arrangement for workers.

At the same time, the SDGs illustrate the centrality to gender justice of demanding an outcome that extends beyond full and productive employment, including a living wage. The SDGs also have other clear wins from which we can draw, no doubt the result of extensive lobbying among women's rights advocates. In turn, working in conjunction with the SDGs offers potential to unearth new ways of quantifying and valuing women's unequal burden of care. Our analysis has also highlighted the ways in which the SDGs may aid in bringing about a more holistic understanding of gender justice. The goals can be used to make visible the multiplicity of spaces in which women move through their days, from workplaces, to markets, schools, and the street. In turn, there also needs to be an evolution in the accountability of fashion companies to ensure that their workers have affordable housing and food, as well as water and sanitation, and healthcare both on and off the factory floor. The six requirements we have presented in this paper, have the ability to bring out these deeply intertwined obligations.

A century has passed since Manhattan's 1911 factory fire. However, much needs to be done to better embed into law and translate into practice protections for women workers. Importantly, while international and national norms are starting to acknowledge the need for gender-responsive approaches to the rights of fashion workers, gaps remain in practice.

\footnotetext{
${ }^{146}$ For instance, a recent study of South Africa shows that while the private sector has a pivotal role to play in countries being able to meet the SDGs, only 6 per cent and 11 per cent in 2016/2017 and 2017/2018 financial year ends, respectively, have incorporated the SDGs into their business model and strategies as reported. See Lorren K Haywood and Mothusi Boihang, 'Business and the SDGs: Examining the Early Disclosure of the SDGs in Annual Reports' (2020) 38:2 Development Southern Africa 1, 6.
} 
The SDGs, which have garnered significant public attention, offer a chance to re-shine the light on the human rights of the women workers in this field.

Conflicts of interest. The authors declare none. 